\title{
Another Side of Global Mobility: \\ Higher Education Access among Students from Refugee Backgrounds
}

\author{
Diep H. Luu ${ }^{1^{*}}$ \\ ${ }^{1}$ University of Massachusetts Amherst, USA \\ "Correspondence: dhluu@umass.edu
}

\begin{abstract}
This project explores how students from refugee backgrounds describe the role of community cultural wealth in their movement into and through their university experience. It analyzes the educational journey of five students from refugee backgrounds. The participants' countries of origin include Egypt, Eritrea, Japan, Togo, and Vietnam. The study followed a narrative inquiry approach and relied on semistructured interviews and their personal statements for university application. This study contributes to the field of comparative and international higher education by bridging the U.S. and international literature and contributes to a synthesis of existing knowledge that may inform the work of educators working with this student population.
\end{abstract}

Keywords: International higher education, refugee students, college access, narrative inquiry

\section{Introduction}

At the end of 2019, 79.5 million people were forcibly displaced worldwide due to conflict or persecution (UNHCR, 2020a). Only $3 \%$ of refugees attend higher education compared to $37 \%$ of the world's youth (UNHCR, 2020b). Promoting educational access among refugees and understanding their experiences in postsecondary education is critical to their success (Unangst, 2020).

The unique needs and challenges of refugee-background students in postsecondary education are consistently under-researched. Students from refugee backgrounds share some characteristics and Received September 18, 2020; revised October 7, 2020, and October 20, 2020; accepted November 1, 2020; electronically published January 31,2021

Journal of Comparative \& International Higher Education

December, 2020, Vol. 12, No. 6S1, pp. 169-173.

DOI: $10.32674 /$ jcihe.v12i6S1.2950

(C) 2020 Journal of Comparative \& International Higher Education. All rights reserved. 
experiences with international students. However, their international background is often rendered invisible because they are not on a student visa and, therefore, not tracked (Luu \& Blanco, 2019). These shared characteristics include: adjusting to a different culture and lifestyle, learning a new language, encountering racism and discrimination inside and outside of the classroom, and reconciling identity crisis when expectations from people at school and at home do not match (McBrien, 2005). On the other hand, refugee-specific characteristics include interrupted education and the first-hand or intergenerational trauma of fleeing their countries of origin and residing in refugee camps (Naidoo et al., 2018).

Educated refugee-background students will have a better chance to contribute to a globalized labor market that demands credentials beyond secondary education (Baum et al., 2013). The purpose of this study is to understand the stories of students from refugee backgrounds who have successfully navigated the U.S. school system and entered higher education. This dissertation study follows an approach focused on the assets and strengths of this population (Kiyama \& Rios-Aguilar, 2018).

\section{Methodology}

The research question guiding this dissertation is: how do students from refugee backgrounds describe the role of community cultural wealth in their movement into and through their university experience? I conducted an in-depth study of the educational journey of five students from refugee backgrounds attending four-year higher education institutions in the United States. The participants' familial countries of origin include Egypt, Eritrea, Japan, Togo, and Vietnam. The study followed a narrative inquiry approach (Clandinin \& Connelly, 2000; Riessman, 2008) and relied on two semistructured interviews with each participant and an analysis of their personal statements for university application. 


\section{Preliminary Findings}

Preliminary findings suggest that successful university students from refugee backgrounds do face challenges and barriers in their schooling that impacted their emotional and psychological wellbeing. These challenges and barriers include lack of language fluency, bullying, identity dissonance, feeling invisible, and lack of cultural and economic capital. Despite these challenges and barriers, they take advantage of their resources, both on and off-campus, to enter higher education and overcome the transition from secondary school to university. Three themes emerged from the preliminary data analysis: developing an appreciation for their national origin identity, finding community through intersections, and unwavering commitment to the future self.

The first theme, developing an appreciation for their national origin identity, is related to participants' stories about how they were bullied in middle and secondary school because of their various identities, including for coming from refugee, immigrant backgrounds. As a result, these students did not feel they belonged in their school settings, and their self-esteem was negatively impacted. Over time, especially in the later years in secondary school and university, these students developed an appreciation for their various social and cultural identities, including their refugee backgrounds. Once these students from refugee backgrounds were grounded with who they are, they made efforts to educate others to fight discrimination, micro-aggressions, and racism in their sphere of influence.

The second theme, finding community through intersections, is connected to the first theme of their unique refugee background identity. Even though the five participants consider their refugee backgrounds as one of their salient social identities, their refugee backgrounds are often not acknowledged in school and university settings. These students from refugee backgrounds did not feel like they could bring their whole refugee background self into any given setting. As a result, these students seek other communities that intersect with their refugee backgrounds identity, such as student 
organizations and campus offices/programs that serve low-income students, first-generation college students, and students of color.

The last theme, unwavering commitment to the future self, refers to a strong commitment to the value of education, motivated by the conviction to transcend the struggles that their parents endured and the sacrifices they made in order to provide their children a better future in the United States. These students were very focused on getting a college degree, even in the face of bullying and self-doubt, in order to fulfill the "American dream," to climb that social mobility ladder for a better future that their parents had hope for their children when they fled their countries of origin. These students are planners. They envisioned the future they want to have for themselves and their families, and they work hard to realize it.

\section{Conclusion}

Discussions of global mobility in higher education often focus on students who choose to, or have the opportunity to, pursue their education in a different country. Another side of global mobility involves those students who must leave their home countries due to violence, displacement, or fear of persecution. This second group, students from refugee backgrounds, are often invisible and inhabit a liminal space: neither fully domestic, nor fully international despite their strong ties to other countries. This study contributes to the field of comparative and international higher education by bridging the U.S. and international literature and contributes to a synthesis of existing knowledge that may inform the work of educators working with this student population. Further research should explore the complexities and entanglements (Stein, 2019) involved in these individual journeys and how they reflect larger networks of displacement and violence. 


\section{Author Note}

Diep H. Luu is a Ph.D. candidate in Educational Policy and Leadership with a concentration in Higher Education at the University of Massachusetts Amherst, USA. His research focuses on college access and equity and student success among students from refugee backgrounds and other underserved student populations.

\section{References}

Baum, S., Ma, J., \& Payea, K. (2010). Education Pays 2010: The Benefits of Higher Education for Individuals and Society. The College Board.

Clandinin, D. J., \& Connelly, F. M. (2000). Narrative Inquiry: Experience and Story in Qualitative Research. Jossey-Bass.

Kiyama, J. M., \& Rios-Aguilar, C. (Eds.). (2017). Funds of Knowledge in Higher Education: Honoring Students' Cultural Experiences and Resources as Strengths. Routledge.

Luu, D. H., \& Blanco, G. L. (2019). Exploring U.S. federal policy discourse on refugee access to postsecondary education. Higher Education Policy. Advance online publication. https://doi.org/10.1057/s41307-019-00144-2

McBrien, J. L. (2005). Educational needs and barriers for refugee students in the United States: A review of the literature. Review of Educational Research, 75(3), 329-364. https://doi.org/10.3102/00346543075003329

Naidoo, L., Wilkinson, J., Adoniou, M., \& Langat, K. (2018). Refugee Background Students Transitioning into Higher Education: Navigating Complex Spaces. Springer.

Riessman, C. K. (2008). Narrative Methods for the Human Sciences. Sage Publications. 
Stein, S. (2019). Critical internationalization studies at an impasse: making space for complexity, uncertainty, and complicity in a time of global challenges. Studies in Higher Education. Advance online publication. https://doi.org/10.1080/03075079.2019.1704722

Unangst, L. (2020). Human rights discourse and the U.S. education landscape: Refugee-specific activity at colleges and universities in Idaho and Maine. In L. Unangst, H. Ergin, A. Khajarian, T. DeLaquil, \& J. W. M. de Wit (Eds.), Refugees and Higher Education (pp. 113-128). Brill/Sense.

UNHCR. (2020a). Global Trends: Forced Displacement in 2019. https://www.unhcr.org/5ee200e37.pdf UNHCR. (2020b). Tertiary Education. https://www.unhcr.org/en-us/tertiary-education.html 